\title{
History-informed strategy research: The promise of history and historical research methods in advancing strategy scholarship
}

\author{
Nicholas S. Argyres, Washington University in St. Louis \\ Alfredo De Massis, Free University of Bozen-Bolzano and \\ Lancaster University \\ Nicolai J. Foss, Copenhagen Business School and Norwegian School of Economics \\ Federico Frattini, Politecnico di Milano \\ Geoffrey Jones, Harvard University \\ Brian S. Silverman, University of Toronto
}

\begin{abstract}
The last decade has witnessed an increasing interest in the use of history and historical research methods in strategy research. We discuss how and why history and historical research methods can enrich theoretical explanations of strategy phenomena. In addition, we introduce the notions of "history-informed strategy research," distinguishing between the dimensions of "history to theory" and "history in theory" and discussing various under-utilized methods that may further work on history-informed strategy research. We then discuss how contemporary research contributes to history-informed research within the strategy field, examine key methodological and empirical challenges associated with such research, and develop an agenda for future research.
\end{abstract}

Acknowledgment: We thank, without implicating, Andrea Colli and Paloma Fernandez Perez for useful discussions of key issues in this article. We are grateful to Constance Helfat and Sendil Ethiraj for their guidance and comments during the review process. 


\section{INTRODUCTION}

Recently, there has been an increasing interest in exploring the nexus between history and strategy (e.g., Braguinsky \& Hounshell, 2015; Leblebici, 2012; Murmann, 2012; Vaara \& Lamberg, 2016). As an illustration of an emerging "historical turn" in strategy research, the number of articles in the Strategic Management Journal that cite the word "history" or "historical" in the title, in the abstract, or in the keyword list grew from 10 in the period 20102014 to 26 in the period 2015-2019. ${ }^{1}$ There are at least three related reasons for this increase.

First, strategy scholars have long had a desire to pinpoint the ultimate sources of firms' sustained competitive advantages (e.g., Barney, 1991; Lieberman \& Montgomery, 1988;

Lippman \& Rumelt, 1982; Oliver, 1997), and have examined firms' historical experiences in this effort (Buenstorf \& Klepper 2009; Helfat \& Lieberman 2002; Moeen 2017). Historical research - that is, "empirical research that uses remote sensing and a contextualist approach to explanation" (Ingram, Rao, \& Silverman, 2012: 249) - is particularly well suited for this task. If firms with sustained competitive advantages are outliers, then the study of such outliers requires going beyond approaches that emphasize averages and discourage examination of extreme data points. A small sample, historical approach may be superior, at least for some purposes (e.g., how the competitive advantage emerged and developed over time). More broadly, historical analysis can be highly useful to strategy research for investigating how the context of contemporary phenomena developed, identifying sources of exogenous variations, developing and testing more informed causal inferences and theories, and more easily supporting analyses of path dependence (Fischer, 1970; Kieser, 1994; Kluppel, Pierce, \& Snyder, 2018).

\footnotetext{
${ }^{1}$ As of $24^{\text {th }}$ July, 2019 . These numbers include early view papers.
} 
Second, strategy scholars have been increasingly interested in understanding how firms make use of history in their strategy processes, and how interpretations of the past influence strategy making (see, e.g., Kaplan \& Orlikowski, 2013; Schultz \& Hernes, 2013). Accordingly, history has been increasingly conceptualized as an endogenous resource that can be proactively managed (Weindruch, 2016). As a result, the last few years have seen numerous strategy papers focusing on uses of history and the past in leading journals (e.g., Anteby \& Molnar, 2012; Godfrey et al., 2016; Hatch \& Schultz, 2017; Suddaby \& Foster, 2017).

Third, there is an emerging interest in using historical information to improve causal identification in strategy (Oxley, Rivkin, \& Ryall, 2010). This interest follows a trend in social science research at large, which has also led to a significant rehabilitation of history in the economics discipline (see, e.g., Kline et al., 2019).

Although history and historical research can be important for advancing strategy research (Colli \& Fernandez-Perez, 2020; Kipping \& Üsdiken, 2014; Kluppel et al., 2018; Miller, Gomes, \& Lehman, 2018) and while the use of historical research methods is the subject of long-lived debate (Bloch, 1949; Cipolla, 2003; Tosh, 2010), the management field lacks precise and consistent definitions of "historical research methods." We define such methods as the class of techniques used for the compilation, description, and critical analysis of primary and secondary historical sources with the intention to provide a contextualized explanation and interpretation of the phenomenon of interest. Primary sources contain unpublished qualitative and quantitative evidence regarding past events, territories, groups, individuals, and their interactions, originated by private and public individuals and organizations, as well as information about the actions of such organizations. Such sources may be archival or oral in nature. Secondary sources are published analyses and descriptions of past events, geographic regions, groups, individuals, and 
organizations. "History-informed strategy research" is then defined as strategy research that draws on historical research methods and/or leverages history as a key component (or variable) of theory or empirical analysis. This dual nature of history-informed strategy research is illustrated in more detail below in the paper.

In the remainder of the paper, we first discuss how and why history and historical research methods can enrich theoretical explanations of strategy phenomena. We then explain how the papers published in this Special Issue contribute to history-informed research within the strategy field. Next, we examine some of the key methodological and empirical challenges associated with history-informed strategy research. Finally, we conclude by proposing an agenda to inform future history-informed strategy research. We aim to encourage the burgeoning interest in the importance of history and historical research methods for understanding strategy determinants, behavior, and outcomes (Kahl, Silverman, \& Cusumano, 2012). Our hope is that this article will contribute to strategy scholarship becoming more informed by historical research, and that such research will earn a prominent place in the strategy field.

\section{HISTORY AS A NEW OLD TREND IN STRATEGY}

\section{A brief history of the history and strategy relation}

Notwithstanding the recent interest in bridging strategy and history, for decades the relationship between the two fields was a distant one. This is a bit odd, given that the emergence of strategy as a discipline was closely tied to developments in business history. Consider some of the key founding contributions to the strategy field. Penrose's (1959) seminal contribution, often seen as establishing the resource-based view of the multiproduct firm and of firm growth (Kor \& Mahoney, 2004; Wernerfelt, 1984), was partly based on her study of the Hercules Powder 
Corporation, originally intended to be included in the book, but removed and published separately in Business History Review (Penrose, 1960). Most directly, Chandler's Strategy and Structure (1962) was "one of the earliest studies in strategic management, preceding the subject's formal existence as a field of research" (Teece, 2012: 69). It is often mentioned as a foundational text, along with Selznick (1957), Cyert and March (1963), Penrose (1959), and Christensen (1969) (e.g., Rumelt, Schendel, \& Teece, 1991). In Strategy and Structure, Chandler, who was to become the doyen of twentieth century business historians, identified the importance of organization-building and management to the growth of modern business enterprises (Whittington, 2008). Employing an inductive investigation of historical documents (e.g., correspondence, reports, memoranda, minutes of meetings) and interviews about the history of four leading US corporations in the first half of the twentieth century, he draws on the interpretation of historical facts and events to develop a number of general propositions, most famously that new organizational structures result from changes in the strategic direction of firms. ${ }^{2}$ The book provided working definitions of strategy and structure. Between 1980 and 2000 - what may be taken to be the period of establishing strategy as an academic enterprise in its own right—Strategy and Structure was the fourth most cited work in Strategic Management Journal, cited by 15 per cent of articles (Ramos-Rodriquez \& Ruiz-Nararro, 2004).

The influence of historical research on strategy continued to grow after the publication of Chandler (1962). Chandler published much more, and his ideas evolved and continued to

\footnotetext{
${ }^{2}$ Chandler's methodological approach influenced many business historians, and the major pillars of this approach were: (i) a historical perspective that focused on identifying change over time in business organization, production, marketing, research, or other functions; (ii) the formulation of clear and compelling research questions to illuminate broad historical change; (iii) a comparative analysis to make sense of why change happened in some firms, or in some industries, or countries, but not others; (iv) the writing of an empirically rich historical narrative, drawn from deep primary and secondary historical sources, that related the chronological sequence of innovation and change; and (v) the use of interdisciplinary perspectives, especially in efforts to conceptualize his historical observations (Jones \& Friedman, 2017).
} 
influence the strategy field (Chandler 1977, 1990). Other work continued to undertake close engagement with historical evidence. Whittington and Mayer (2000) updated Chandler's work with regard to European corporations. Pettigrew (1985) studied the relationship between change in organization and external context through a case history of the Imperial Chemical Industries

company. Kirsch and Mom (2002) drew on extensive historical materials to explain the failure of the first electric vehicle company in the U.S., which suggests implications for competition among alternate technological systems. Studies of the strategies and structure of business groups have utilized rich historical evidence (Colpan \& Hikino, 2018). McKendrick and Carrol (2001) conducted a longitudinal historical analysis of disk-arrays producers in the USA to study the emergence and adoption of different organizational forms. Cattani, Dunbar, and Shapira (2012) examined how value is attributed to a cultural product by studying the history of the Cremonese stringed instruments. Braguinsky (2015) utilized historical data about the Japan's early cotton spinning industry to illuminate the relationship between knowledge diffusion and industry growth. Gao, Zuzul, Jones, and Khanna (2017) used a large oral history database to examine the importance of reputation in corporate longevity in emerging markets.

These works are examples of a small but expanding group of history-informed strategy studies that have appeared in academic journals starting from the 1980s. In the next section, we offer a more detailed and structured overview of this emerging field of research at the nexus between strategy and history, with the aim of providing insights about what strategy researchers can learn from history scholarship.

\section{The promise of history for strategy research}

By drawing on the work of Kipping and Üsdiken (2014), we argue that the value of history for strategy scholarship has a dual nature. On the one hand, historical research methods offer 
strategy researchers novel and powerful tools to develop new or modify and test existing theories, by allowing access to historical data, and applying historical conditionality to build and test theories in a context-specific manner. We suggest therefore that the critical contribution of historical research methods to strategy scholarship lies not only in the use of valuable historical data, but also in the application of an "historical cognizance" perspective (Kipping and Üsdiken, 2014), indicating the opportunity to incorporate in a more fine-grained, nuanced and interpretivist way period effects and historical contingencies into the theorizing process. On the other hand, history and the use of the past can be incorporated into theoretical models, to enrich theoretical explanations of strategy phenomena, thus becoming an important variable in itself in strategy theories. These two dimensions are labelled as "history to theory" and "history in theory," respectively (Kipping \& Üsdiken, 2014). History-informed strategy research is therefore research that is informed by these two dimensions of the nexus between history and strategy, that is, it uses historical research methods to build and test theories in a context-specific manner and/or it incorporates history into its theoretical models.

Regarding the former perspective, that is, "history to theory"--it is important to acknowledge that historical research methods that place actions and events into the contexts in which they took place and provide a critical, interpretivist explanation of their causal relationships can shed light on the determinants and processes that shaped organizational outcomes (e.g., Holbrook, Cohen, Hounshell \& Klepper, 2000; Klepper, 2002; Klepper \& Simons, 2000, 2002). For example, this approach can help establish the causes of strategic decisions, and of performance differences among organizations (Kluppel et al., 2018). More contextualist approaches can also help overcome limitations of large- $\mathrm{N}$ research, which often requires specific econometric assumptions, frequently cannot uncover in a detailed way the mechanisms of action and the 
complex unfolding of how individuals, groups and organizations interact with the external context to experience a given research phenomenon, and often cannot explain extreme data points. Adopting historical research methods allows scholars to focus on the extremes, to study in detail (for example) how a firm developed a sustainable competitive advantage over time. Overall, these methods allow one to investigate how the context of strategic phenomena emerged, to develop richer and more contextualized causal theories of competitive advantage, and to support analyses of path dependence or the "shadow of the past." Indeed, historical research methods have been used to study a diverse set of topics, such as industry evolution (Klepper, 2016; Malerba et al., 1999; McKenna, 2006), technology strategy (Cusumano \& Selby, 1995), dynamic capabilities (Danneels, 2011), asset ownership (Hansen \& Libecap, 2004; Silverman \& Ingram, 2017), and the shadow of the past in the survival of new firms (Geroski, Mata, \& Portugal, 2010). Moreover, history can be used as an empirical laboratory to answer research questions that require the study of long-time horizons. Longitudinal datasets, because they allow for more variation than cross-sectional data, often provide better testbeds. Institutional studies in strategy, for example, often use time-series data such as daily event-history data (see, e.g., Rao \& Dutta, 2012) and historical narratives based on primary and secondary source data (see, e.g., Rowlinson \& Hassard, 1993). Historical research methods and data are also useful for studying change and strategy-making phenomena as they unfold over time. For example, by focusing on temporal sequences of events and actions, they facilitate the development of process models (see, e.g., Burgelman, 1983; Van de Ven \& Huber, 1990). Finally, historical research is also helpful for modelling and understanding strategic decisions and interactions. Thus, historical analysis can inform game theoretic models (Ghemawat, 1997) and help parametrize simulation models (Malerba, Nelson, Orsenigo, \& Winter, 2008). Other examples of strategy papers in the 
"history to theory" tradition include some papers belonging to the organizational ecology field. For example, Carrol and Hannan (2000) studied the impact of different environmental factors such as resource availability, technological innovation, and political changes on the demography of corporations and industries. Similarly, institutional theory and institutional ecology scholars have often turned to historical research methods to build richer explanation of their phenomena of interest. For instance, Hargadon and Douglas (2001) provided an account of the introduction of Edison's electric lighting system as a case of institutional entrepreneurship and strategic change, and Dobbin and Dowd (1997) used a historical perspective to theorize about the impact of public policies on competition and business strategies.

Regarding the "history in theory" perspective, historical research has been used to examine how actors strategically develop interpretations of historical facts that shape their present behavior and set expectations for the future (Carr, 1961; Koselleck, 2004). It has also been used to study how actors use knowledge and resources from the past to set future directions, and to create a durable competitive advantage (De Massis et al., 2016). Applications of evolutionary economics (Nelson \& Winter, 1982) to strategy focus less on individual actors, and more on how organizational learning and other sources of path dependence combine to determine firm boundaries, survival, and competitive advantage (e.g., Winter 2003; Jacobides \& Winter, 2005, 2007; Jacobides, Winter, \& Kassberger, 2012). Recent studies have also paid attention to the role of history in organizational processes (Schultz \& Hernes, 2013) highlighting how actors leverage the "power of the past" as they reproduce tradition and heritage (Weber \& Dacin, 2011). Imprinted tradition and routines and rituals based on shared history can continue or decay over time, depending on specific traditionalizing mechanisms (Marquis \& Tilcsik, 2013; Simsek, Fox, \& Heavey, 2015). Recent research has investigated, for instance, how the long-lasting legacy of 
previous generations can shape the strategies of the current generation in long-established firms (Erdogan, Rondi, \& De Massis, 2019). This holds implications for the imprinting literature, which of course strongly emphasizes the role of tradition (Stinchcombe, 1965; Tilcsik, 2012) as well as for the entrepreneurial legacy literature (Jaskiewicz, Combs, \& Rau, 2015), which studies the rhetorical reconstruction of past entrepreneurial achievements that are imprinted, transferred, and interpreted between and among generations during the organization's historical evolution (Hammond, Pearson, \& Holt, 2016). Similarly, historical legacies outside the organization can shape the opportunity sets available to actors (Greve \& Rao, 2012, 2017). From this perspective, history is not conceptualized merely as "data" or as a "methodological approach" to examine these data, but rather as an important component of the theories that strategy scholars build. History is thus treated as an endogenous resource that can be created and/or managed by strategy makers, or as a contextual variable constraining and influencing strategic decisions. Other examples of strategy papers in the "history in theory" tradition are those in the field of structural and organizational inertia. These are studies that typically refer to historical conditioning of both incentives and capabilities that then guide future action at individual and/or organization level. For example, Amburgey \& Miner (1992) studied how merger experience is linked with later merger activities and performance in large U.S. firms, and Amburgey, Kelley \& Barnett (1993) focused on the role of the past in determining strategic changes. Similarly, studies in the capabilities field often incorporate the past and the lock-in deriving from it in their theoretical model (see, e.g., Anderson \& Tushman, 1990; Danneels, 2011 and Tripsas \& Gavetti, 2000; Leonard-Barton, 1992).

\section{EXTENDING STRATEGY RESEARCH THROUGH THE USE OF HISTORY:}




\section{THE PAPERS IN THIS SPECIAL ISSUE}

The papers in this special issue clearly demonstrate the benefits of applying historyinformed research within the strategy field. ${ }^{3}$ Table 1 provides an overview of the papers published in this Special Issue, highlighting the type of research questions they answer, and their positioning in the "history to theory" and "history in theory" dichotomy. We consider them in turn.

\section{Insert Table 1 here}

In a fascinating study of the birth of the automobile industry, Pillal et al. (this issue) explore empirical regularities in the actions taken by successful early firms. The automobile industry is one of the most studied industries in the management literature (e.g., Abernathy \& Clark, 1985; Argyres et al 2015; Kirsch, 2000; Klepper, 2002, 2007; Klepper \& Simons, 2000), with much effort invested in understanding what characteristics led some firms to long-term success and others to early failure. Intriguingly, much prior research bifurcates between touting early investment/ commitment on one hand (e.g., Klepper, 2002) and flexibility or experimentation on the other (e.g., Abernathy \& Clark, 1985). Related to this is a debate around the "paradox of entrepreneurship" (Gans et al., 2019), whereby early experimentation is touted as beneficial (Ries, 2017) but the very action of experimenting will often commit an organization to a certain path. Pillai et al. contribute to this debate by detailing early experimentation efforts by young automobile producers in terms of new models, and demonstrate that the most successful U.S. auto firms were those that made risky commitment-inducing experiments to new models (what the authors term "strategic pivots"). Of particular interest, their deep reading of firm

\footnotetext{
${ }^{3}$ This Special Issue received 124 submissions, which demonstrates a strongly increased interest by scholars from different disciplines in research at the intersection of history and strategy.
} 
histories reveals that successful firms undertook these pivots in order to learn about the market and about their own capabilities and constraints, and subsequently changed their approaches to product design, supplier relations, pricing, and many other decisions so as to reduce the risk associated with the next pivot. This study deepens our understanding of entrepreneurial strategy by shedding light on the specific practices that distinguish successful vs. unsuccessful early entrants. Yet it also links to commitment and the resource-based view, in that 1) these early experiments led to effective commitments that subsequently drove a firm's trajectory and presumably influenced the competitive action of potential rivals, and 2) the firm-specific learning obtained from experimentation created valuable resources that were not easily observable to rivals. Thus, managing the shift from short-term flexibility to long-term strategic investment was a crucial strategic challenge for the young firms they studied. This paper is an interesting example of history-informed strategy research which combines both the "history to theory" and "history in theory" perspectives outlined in this introduction. Indeed, it not only uses rich, contextualized historical data to provide a deeper understanding about what distinguishes successful versus unsuccessful early entrants, but it also conceptualizes economic experimentation as an historical learning mechanism that influence the future actions of new entrants.

Wadhwani et al. (this issue) focus on an intriguing question: how might multinational firms develop strategy to take advantage of economic nationalism in host countries? The authors explore the actions of German multinational enterprises (MNEs) operating in India during the two decades preceding the World War II, near the tail end of British colonial rule. During this period, the Indian populace was increasingly eager for self-rule and thus increasingly antiBritish. Economic nationalists were keen to boycott British products. Wadhwani et al. study the 
actions of Bayer and Siemens, and note in rich and nuanced detail how these firms were able to position themselves as "outsiders" to colonialism, thus gaining favor among the populace. Crucially, this entailed the development of specialized political capabilities to monitor and respond to sensibilities in both host and home countries. Beyond the compelling setting and analysis, this study clearly informs and extends more general strategy research. The literature on multinational strategy commonly examines the deployment of firm-specific assets in appropriate country settings through a lens of organizational economics or capabilities (Hennart \& Park, 1993; Zhao, 2006); research that draws on non-market strategy has augmented this with an understanding of political and institutional factors (e.g., Henisz, 2000, Henisz et al., 2014). Yet, by conceiving India as a nation-state rather than a country, and incorporating historical sensibility concerning nation-states, Wadhwani et al. introduce concerns of national identity, substantially enriching our conception of MNE strategy and shedding light on an overlooked set of strategic levers to support what they term "geopolitical jockeying." This work not only expands and deepens the range of questions that MNE strategy research can ask, but also points to potential complementarities with ideas about raising rivals' costs and with a view of legitimacy that is more nuanced than the generic liability of foreignness. In addition, it clearly demonstrates that when the barrier to enacting change resides outside the firm - as in a population with a national identity - then the ability of some firms (in this case British MNEs) to act is severely constrained.

The importance of national identity for international strategy is amplified in Arikan et al. (this issue). Analyzing a panel dataset consisting of cross-border alliances, joint ventures and acquisitions, the authors show that past conflicts between two countries reduce the present likelihood of these kinds of economic activities, and that this effect lasts for decades before 
diminishing. Thus, current patterns of cross-national economic organization cannot be fully understood without understanding the long histories of conflicts among nations. Intriguingly, the authors also find evidence that the negative effect of historical conflict on cross-border arrangements dissipates more quickly when the nations' populations are more highly educated (in fields that are plausibly business-related), suggesting ways in which institutional legacies of this type might be more prone to change. The contribution by Arikan et al. can be seen as reflecting both "history to theory" and "history in theory." With regard to the former, the paper shows how patterns of firm strategies are better understood when firms' national historical contexts are taken into account. With regard to the latter, the paper suggests ways in which theories of path dependence and imprinting can be enriched with historical data.

Agarwal et al. (this issue) and Lamberg and Peltoniemi (this issue) both apply a historyinformed approach to uncover new insights into the patterns of firm growth and survival during the evolution of an industry. Agarwal et al. study the first 30 years of the Japanese cottonspinning industry, an important and technologically sophisticated industry born near the end of the $19^{\text {th }}$ century. After demonstrating that the industry exhibits the traditional pattern of population dynamics, the authors exploit remarkably detailed data on management teams including the actual responsibilities handled by each top executive, rather than just the executive's title - to explore the relationship between management team and firm growth/survival. They find that the most important success factor for the cohort of early firms was long-term stability in shared leadership of the firm among two or more executives, reflecting the ability to benefit from diverse knowledge, as well as to prevent and recover from disagreements within the top management team. This worked particularly well for firms that also overcame traditions limiting the promotion of educated engineers who were not from prominent 
families. As the authors note, this is consistent with Penrose's (1959) view that the management team is frequently a key resource of a firm. Thus, this study not only extends our understanding of industry evolution by adding rich insights about which firms survive, but also links it directly to the resource-based view in ways that highlight a fruitful roadmap for future research.

Lamberg and Peltoniemi's study of the Finnish pulp and paper industry over its nearly 200-year life, which included several entry cohorts over time, demonstrates that long-run success was predicated on a firm's willingness and ability to make major investments at key historical junctures. The institutional factor of business group membership was in turn important in determining firms' abilities to make key investments. Thus, as in Pillai et al., a willingness to make commitments at an opportune moment played an important role in firm success. Intriguingly, the authors find that executives required more favorable circumstances to initiate new investments than to continue investments that had already begun, perhaps indicating a sunkcost bias in decision-making. The authors also take advantage of the waves of entry into the industry to reveal that different types of pre-entry experience matter at different times during the industry's life. In addition to advancing our knowledge of industry evolution, the study also highlights the role of adjustment costs (of both the economic and cognitive inertia variety) more explicitly than in much prior work. This paper is another example of combination of the "history to theory" and "history in theory" perspectives. It makes use of a rich, longitudinal and contextualized historical database to study the sources of long-term success, but it also conceptualizes pre-entry experience as a mechanism through which firms learn from the past and which influences future actions.

The remaining three articles in this special issue focus on managers' use of history to interpret strategic challenges/opportunities facing the firm, or to inspire and persuade 
stakeholders to embrace their strategic decisions. Recent work on dynamic capabilities has increasingly focused on the micro-foundations of such capabilities (e.g., Adner \& Helfat, 2003; Felin et al., 2012; Helfat \& Peteraf, 2015). Suddaby et al. (this issue) explicitly propose that executives' capacity to manage history is in fact a critical cognitive input to the micro-foundation of a dynamic capability. In this conceptual paper, the authors argue persuasively that three distinct aspects of managing history align closely to the three elements of dynamic capabilities as specified by Teece (2007). Specifically, a good objective understanding of history leads to better sensing of opportunities. Likewise, effective use of rhetorical history facilitates the seizing of opportunities by using stories of the past to mobilize resources. Finally, compelling use of imaginative history facilitates reconfiguring by supporting what the authors call "future-perfect thinking." Suddaby et al.'s formal propositions lay out a roadmap for future research on history as a micro-foundation of dynamic capabilities. Beyond this, the paper underscores the importance of history to both guiding senior management strategic choices and inspiring other stakeholders to accept and endorse these choices. Particularly with regard to the latter of these, the authors highlight potential linkages to the imprinting, institutional legacies, legitimation, and social categorization literatures, in which the judicious use of rhetorical or imaginative history may enable the cognitively endowed management team to relax the constraints imposed by these traditional barriers to change.

Sasaki et al. (this issue) focus primarily on rhetorical history, noting that recent research in this area raises questions about the malleability of the past (Schultz \& Hernes, 2013; Suddaby et al, 2010; Ybema 2014). The authors examine these questions through a deep and fascinating exploration of change initiatives at Japanese family firms, analyzing executives' attempts to reconcile such initiatives with longstanding corporate value statements or "mottoes" promulgated 
by revered predecessors. Their analysis reveals three distinct strategies employed by executives: re-articulating the historical statement's content and extending its implications to the current context ("elaboration"); forging a new statement that recombines historical references ("recovering"); and creating a new value statement that co-exists in parallel with the old one (“decoupling"). Intriguingly, each strategy is used in distinct circumstances; for example, elaboration is more prevalent during incremental change while recovering is more prevalent in the face of more sudden, externally-driven change. This study provides important new evidence regarding the degree to which rhetorical history can be used to reimagine the past, and the ways in which strategists can best employ rhetorical history. In addition, it highlights links between rhetorical history and impression management to inform the feasibility of overcoming - at least in part - the constraints of imprinting among top management and legitimation among stakeholders.

Sinha et al. (this issue) also examine rhetorical history, but focus on their use by senior management to guide strategic choices. The authors study the 80-year history of the Gallagher Group, a successful New Zealand-based family firm that produces agricultural equipment, notably electric fencing systems. The firm's life can be categorized into phases that involved the management of different challenges and opportunities, such as a domestic expansion phase, an internationalization phase, and a crisis phase triggered by macroeconomic and international trade-driven events. Of particular note, Sinha et al. demonstrate how a small set of historical narratives - stories of how the firm overcame challenges in the past - became codified into what they call "strategic guideposts" that were consistently used to navigate new situations. They also describe how these strategic guideposts became divorced from the broader narratives, and how exaggeration and "strategic forgetting" extended the use of the guideposts. Intriguingly, during 
the one period of Gallagher Group's history that required temporary suspension of the guideposts, the firm brought in an outside non-family executive to manage the challenge, subsequently replacing him when it was feasible to reinstate the guideposts. In addition to deepening our insight into the strategic use of historical narrative, this study also offers provocative links to the imprinting literature, especially in the family firm setting (Erdogan et al., 2019). The authors postulate that strategic guideposts serve as a form of "second-hand imprinting" that survives a specific narrative and counteracts the fading of imprinting (Marquis \& Tilcsik 2013).

In sum, the eight papers in this issue collectively demonstrate the wide range of phenomena and portfolio of theoretical lenses that can benefit from history-informed strategy research. They are also representative of the two dimensions that characterize the concept of history-informed strategy research put forward in this paper. Thus, the papers by Agarwal, Braguinsky \& Ohyama and Wadhwani \& Lubinski are examples of "history to theory" research, as they use historical research methods to build and test theories in a context-specific manner. The papers by Sasaki, Ravasi, Kotlar \& Vaara, Sinha, Jaskiewicz, Gibb \& Combs, and Suddaby, and Coraiola, Harvey \& Foster apply a "history in theory" perspective as they incorporate history and uses of the past into their theoretical models. And the papers by Arikan, Arikan, \& Shenkar, Lambert \& Peltoniemi, and Pillai, Goldfarb \& Kirsch combine "history to theory" and "history in theory" perspectives.

\section{METHOD CHALLENGES AND FUTURE RESEARCH DIRECTIONS AT THE INTERSECTION OF HISTORY AND STRATEGY}

In the following, we identify and briefly discuss a set of method challenges and directions for future research in strategy, for which a history-informed approach is likely to be particularly 
fruitful.

We begin by discussing some key methodological challenges that open up avenues for future research in the "history to theory" perspective. Then, we move into illustrating some promising opportunities for incorporating history and uses of the past into strategy theories ("history in theory" perspective).

\section{Datasets, causation, and thought experiments ("history to theory" directions)}

Pursuing history-informed strategy research calls for datasets that trace over time how organizations, groups, and/or individuals, by taking decisions and acting in a particular historically embedded context, and by mutually interacting, have achieved specific organizational outcomes such as growth, survival and sustainable competitive advantages or failed to do so. For example, specific organizational outcomes such as growth and sustainable competitive advantages may have developed by enacting effective learning processes or developing superior capabilities over time. Datasets that are amenable to statistical analysis may be generated from the archives of individuals or firms by integrating different primary historical sources, such as unpublished evidence regarding past events, geographic regions, groups, individuals, and their interactions as well as information about the actions of organizations. As mentioned above, such evidence may have been originated by individuals, private or public organizations, or may be reflected in secondary historical sources, such as published analyses and descriptions of past events, territories, groups, individuals, and organizations. In addition, there is a need for creative applications of new methods and levels of analysis to such datasets, including the individual level of inquiry ("microfoundations") in which individuals' economic incentives, psychological biases and heuristics are studied with an eye toward explaining macro- 
level phenomenon (Felin, Foss, \& Ployhart, 2015). Indeed, a history-informed approach promises to ground microfoundational research more solidly in empirical reality, thereby overcoming an important challenge to such research (cf. Felin et al., 2015). An history-informed approach can allow for a rich and fine-grained account of individual decision-making in a specific context, which in turn facilitates the examination of how cause and effect play out across levels of analysis. In addition, archival data can provide unique insights into the interplay between entities at different analytical levels. For example, the recent paper by Braguinsky and Hounshell (2015) combines nanoeconomics with historical research methodology and quantitative empirical analysis to illuminate the coevolution of firms and industry in the Meiji Era Japanese cotton spinning sector (see also Klepper, 2011). Research that draws on the academic history field, particularly the study of prehistory and ancient history, to introduce historiographical ${ }^{4}$ analyses of past events, as well as to examine objects and non-literary sources, also holds promise for strategic research.

Second, counterfactual approaches can be used to advance current understanding of causation in strategic processes and to clarify the construction of competitive advantages (Durand \& Vaara, 2009). Thus, counterfactual history methods (Collins, Hall, \& Paul, 2004; Lewis, 1973, 1986) and related modeling techniques (e.g., Bayesian narratives, causal graphs, and counterfactual testing and evaluation; cf. Morgan \& Winship, 2007; Pearl, 2000) can add to our understanding of the context-specific construction of competitive advantage based on resource stocks coming from the past. In addition, causal modeling - that is, the development of

\footnotetext{
${ }^{4}$ Historiography is defined as "the study of the writing of history" (Tosh, 2010: 65). Explaining how a historian approaches historical events is one of the key areas of attention within historiography. It is commonly recognized by historians that, in themselves, individual historical facts dealing with names, dates and places are not particularly meaningful. Such facts will only become meaningful and therefore useful when combined with other historical evidence. The process of assembling this evidence is understood as a particular historiographical approach (e.g., the Marxist, "Annales", "total history", or political schools of historiography).
} 
models representing causal mechanisms within a system so as to make predictions about the behavior of a system (or sub-systems) $)^{5}$ - can help to re-conceptualize the relationships between resources and performance in a temporal perspective, for example by helping to disentangle whether the use of specific resources will enable the pursuit of a particular strategy or, on the other hand, whether the decision to execute a particular strategy will drive search toward resources from the past. While these approaches are well known in the philosophy of science (Collins et al., 2004; Lewis, 1973; Woodward, 2003) and applied in historical analysis (Ferguson, 1997; Tetlock \& Belkin, 1996), they have not been given much attention in strategy research. Nevertheless, they can play a central role in causal reflection and inference. Indeed, such reasoning is particularly important in order to understand the role of the past in strategy processes. Counterfactual approaches can be applied both in qualitative (Tetlock \& Belkin, 1996, Tetlock, Lebow, \& Parker, 2006) and quantitative analyses (Morgan \& Winship, 2007; Pearl, 2000). Quantitative analysis is more common in strategy, while qualitative analyses may include case studies, ethnographies or narrative analyses of individual biographies, family histories, genealogical tools, prosopographical approaches ${ }^{6}$ to a group of individuals and/or families, compilations of news from journals and magazines about a particular theme. Qualitative comparative analysis (QCA) is a data analysis technique that bridges quantitative and qualitative

\footnotetext{
${ }^{5}$ In particular, a causal model entails the truth value, or the probability, of counterfactual claims about the system; it predicts the effects of interventions; and it entails the probabilistic dependence or independence of variables included in the model. Causal models also facilitate the inverse of these inferences: if the probabilistic correlations among variables, or the outcomes of experimental interventions, have been observed, then it is possible to determine which causal models are consistent with these observations.

${ }^{6}$ In historical studies, prosopography is an investigation of the common characteristics of a historical group (whose individual biographies may be largely untraceable) by means of a collective study of their lives, in multiple careerline analysis. Prosopographical approaches (e.g., Stone, 1971; Keats-Rohan, 2007) refer to research approaches where the main goal is learning about patterns of relationships and activities through the study of collective biography; such approaches typically collect and analyze statistically relevant quantities of biographical data about a well-defined group of individuals.
} 
analysis, and can also prove particularly powerful for the counterfactual analysis of causal complexity (Greckhamer et al. 2018; Ragin 2014). ${ }^{7}$

Third, thought experiments (De Mey \& Weber, 2003) and fiction (White, 1987) can also be suitable for performing systematic analysis of "what-if questions" around the key mechanisms through which competitive advantage can be built over time. Thought experiments are a means to explore a concept or build an interpretation of a phenomenon through extensive thought, and they can be especially useful when empirical evidence about the focal phenomenon is very scarce or absent, for instance because the phenomenon has not yet occurred. In this sense, thought experiments can be useful for understanding how strategic behavior or the sources of the competitive advantage of a firm change in rare circumstances, such as in a natural disaster, a political upheaval or a terrorist attack. By following the rules that academic historians apply when addressing these what-if questions (see, e.g., Hawthorn, 1991) and contrasting conceptual development with well-established historical events, it is possible to build theory about strategy phenomena under rare conditions.

Finally, strategy studies have of course benefitted from case study-style research, as well as quantitative historical data, to establish their claims. While many of such studies have offered very detailed qualitative and quantitative analyses, historical research methods are well suited to feature the level of depth and comprehensiveness that the study of complex strategy phenomena may require. History-informed research offers the potential to assess attempts by firms to manipulate their audiences, or the degree to which their failures reflect cognitive biases or

\footnotetext{
${ }^{7}$ With QCA, it is possible to assess causation that is very complex, involving different combinations of causal conditions capable of generating the same outcome. QCA also facilitates a form of counterfactual analysis that is grounded in case-oriented research practices.
} 
adjustment costs. Such conclusions are difficult to reach from aggregate statistical data only, or from case studies of limited depth.

Table 2 provides more details about the four methodological challenges and opportunities outlined above. The application of the historical research methods discussed for each challenge/opportunity to study strategy phenomena would allow history-informed strategy research to move forward along the "history to theory" direction (Kipping \& Üskiden, 2014). Insert Table 2 here

\section{"History in theory" directions}

We now identify some research directions that represent promising future "history in theory" opportunities to expand history-informed strategy research. Table 3 summarizes some questions for future research. This research agenda is not meant to be exhaustive, but is instead to provide some particularly interesting research questions that deserve attention.

------- Insert Table 3 here --------

A first promising direction for future research involves drawing on history and historical research methods to put historical context in the front seat of strategy theorizing. The influence of the context (e.g., the industry) is a long-standing assumption in strategy studies (De Massis, Kotlar, Wright, \& Kellermanns, 2018), yet the mechanisms through which the context shapes strategy behavior and the processes through which individuals, groups and organizations interact with the context to achieve or fail to achieve specific organizational outcomes such as growth, survival or a sustainable competitive advantage remain largely under-theorized and little understood as most strategy studies at best use contextual variables as control variables in their studies. We encourage strategy scholars to develop new and better-informed theoretical interpretations of strategy phenomena, which are more explicitly embedded in the historical 
context in which they take place, and focus on the complex temporal dimensions through which they occur. For instance, scholars could explore how exogenous shocks or environmental jolts happening during the course of history (e.g., cyclical financial turmoil, sectorial disruptions at some stages of modernization; Kluppel et al. 2018) influence specific strategic behaviors (e.g., innovation, internationalization, strategic change). They could also study how decision makers' perceptions of time and/or their temporal foci influence the strategic goals and purposes of their organizations, and changes in them. A conventional view of history considers it as an authoritative and single formal record of the past (Ranke, 1824) and conceives historical analysis as "[...] empirical research that uses remote sensing and a contextualist approach to explanation" (Ingram et al., 2012, p. 249). This indicates that historical analysis can be useful to strategy research for understanding the context of contemporary phenomena, identify sources of exogenous variations, develop and test more informed causal inferences and theories, and more easily support analyses of path dependence (Fischer, 1970).

One area ripe for future research is the study of how organizations, groups and individuals use the past to give meaning to the present, inform their expectations about the future, and take strategic decisions (Kosseleck, 2004). Such research could study the ways in which the past informs how organizational goals are set (Kotlar \& De Massis, 2013), how future technology and market trends are forecast (Durand, 2003), how new business opportunities are identified, evaluated and exploited (Foss, Lyngsie, \& Zahra, 2013). Path dependency explains that the decisions an organization is confronted with are influenced and limited by the decisions it has made in the past (Greve \& Seidel, 2015). However, we need more fine-grained theoretical explanations of how specific and non-recurrent events or actions that occurred in the past - and embedded in a particular historical context -led to particular strategic behaviors and to the 
development of organizational capabilities. This view suggests the importance of adopting an historical embedded approach to studying how organizations learn, innovate and take strategic decisions over time (Vaara \& Lamberg, 2016).

A second direction for future research entails investigating how knowledge and resources pertaining to the past are used to trigger and realize acts of organizational change, entrepreneurship and innovation. Some research portrays the past as a negative force, leading to organizational inertia, liability of senescence (Barron et al., 1994), core rigidity (Leonard-Barton, 1992), and resistance to change (Barron et al., 1994; Leonard-Barton, 1992). Other research suggests that firms can create competitive advantage through acts of innovation, entrepreneurship and organizational renewal by searching for, accessing, and using knowledge created at different points in the past, a process known as temporal search (Katila, 2002). For instance, 3M radically innovated the flexible circuit business with 3M Flex, a solution developed by using technologies the firm had almost abandoned in the 1980s. Similarly, the world-leading Danish hearing aid manufacturer, Oticon, saved itself from bankruptcy by developing the Multifocus hearing aid, which was based on much earlier breakthroughs the companies had shelved years before (Foss, 2003).

These examples suggest additional research questions. What are the firm-, individual- and group-level capabilities required to successfully search for and recombine knowledge resources coming from the past? How do firms learn to innovate their products, services, business models, procedures and strategies from the past? How do innovation processes and practices evolve over time, and how are they shaped by the interactions between firms and the past? Understanding how temporal search processes unfold over time, and identifying the antecedents and consequences on resource-based competitive advantage and firm performance, require careful 
placement in the historical context in which knowledge was generated, searched, retrieved and used for innovation and change purposes. How do exogenous historical events change firms' search behavior and strategic choices in response to the new opportunities and threats they generate? Connecting past, present and future in a meaningful way requires rigorous causal theorizing. In this regard, "history-friendly" evolutionary economic modeling (Malerba et al., 1999, 2001; Malerba \& Orsenigo, 2002) can be helpful to capture, in a stylized form, a causal theory about the mechanisms and factors affecting the historical evolution of an industry or technology, and enable their exploration. Through faithful representation and formalization of verbal arguments, such modeling has the potential to sharpen our understanding of the role of the past in temporal search.

A third avenue for future research, which is closely intertwined with the previous ones, questions the predominant conceptualization of time in strategy studies (Lippmann \& Aldrich, forthcoming). The predominant view adopts a linear conceptualization of time, according to which organizational change occurs through a linear progression that moves the past into the present, and then into the future (Lord, Dinh, \& Hoffman, 2015). Put differently, time is typically assumed to unfold in steady and largely predictable ways. For example, in this perspective, strategic decisions are treated as starting from the desired future competitive stance of the firm (Eisenhardt \& Zbaracki, 1992). This perspective places less emphasis on the unpredictable, nonrecurrent events that often change the course of history and the evolution of organizations, and does not allow researchers to capture how individuals, groups and firms conceive time in practice and allocate their attention differently to the past, present and future (Lippmann \& Aldrich, forthcoming). An alternative perspective considers time to be a complex, socially constructed concept, which can be perceived by individuals, groups and organizations in multiple 
ways (Aldrich, 2009). Decisions makers can have different temporal foci and shift their attention to various points in time (Shipp, Edwards, \& Lambert, 2009). Accordingly, they may ground their strategy making processes primarily in their perception of the past performance or conditions of the firm. This calls for a deeper study of how different temporal foci influence the performance of teams and organizations. Moreover, history suggests that time is not a given process that unfolds separately from individuals, groups and organizations. Instead, there are multiple conceptions of time which operate in parallel (Braudel, 1982). This indicates the importance of including a more fine-grained understanding of the temporal orientation of decisions makers in strategy research (Holman \& Silver, 1998) and of studying how temporal orientation changes under the influence of different individual, firm-, or country-level variables. For instance, recent abductive research (Erdogan et al., 2019) has suggested that temporal symbiosis, defined as an organization's simultaneous adoption of retrospective and prospective approaches to using its resources to concurrently perpetuate tradition and achieve innovation, is a capability that helps family firms to develop and sustain a competitive advantage across generations.

\section{CONCLUSION}

We believe that a history-informed agenda in strategy research is both timely and warranted because history allows us to develop more informed causal theories about the achievement (or failure to achieve) of organizational outcomes such as growth, survival or a sustainable competitive advantage. In this article, we have discussed historical research methods, highlighted the need to embrace history-informed strategy research, and examined under-utilized methods that are helpful for this area of study. We have also proposed an agenda for future research by delineating some important methodological challenges and research directions related to the 
"history to theory" and "history in theory" dimensions of history-informed strategy research. Given the many benefits associated with drawing on history and historical research methods in strategy, and the methodological and data challenges associated with history-informed strategy research, we have only scratched the surface of the issues that need to be investigated.

Nevertheless, we will consider our efforts to have been successful if we have encouraged scholars to tackle some of the research questions that an history-informed approach to strategy studies suggests. 


\section{REFERENCES}

Abernathy WJ, Clark KB. 1985. Innovation: Mapping the winds of creative destruction. Research Policy 14(1): 3-22/

Adner R, Helfat, CE. 2003. Corporate effects and dynamic managerial capabilities. Strategic Management Journal 24(10): 1011-1025.

Aldrich HE. 2009. Lost in space, out of time: how and why we should study organizations comparatively. In B. King, T. Felin, D. A. Whetten (eds). Studying Differences Between Organizations: Comparative Approaches to Organizational Research. Emerald Group: Bingley, UK.

Amburgey, T. L., Kelly, D., Barnett, W. P. 1993. Resetting the clock: The dynamics of organizational change and failure. Administrative Science Quarterly 38(1), 51-73.

Amburgey, T. L., Miner, A. S. 1992. Strategic momentum: The effects of repetitive, positional, and contextual momentum on merger activity. Strategic Management Journal 13(5): 335348.

Anderson P., Tushman M. L. 1990. Technological discontinuities and dominant designs: A cyclical model of technological change. Administrative Science Quarterly 35: 604-633.

Anteby M, Molnar V. 2012. Collective memory meets organizational identity: remembering to forget in a firm's rhetorical history. Academy of Management Journal 55(3): 515-540.

Argyres, N, Bigelow, L, Nickerson, J. 2015. Dominant designs, innovation shocks, and the follower's dilemma. Strategic Management Journal, 36(2): 216-234.

Argyres, N, Mahoney, J, Nickerson, J. 2019. Strategic responses to shocks: Comparative adjustment costs, transaction costs, and opportunity costs. Strategic Management Journal, 40(3): 357-376.

Barney J. 1991. Firm resources and sustained competitive advantage. Journal of Management 17(1): 99-120.

Barney JB. 2001. Resource-based theories of competitive advantage: a ten-year retrospective on the resource-based view. Journal of Management 27(6): 643-650.

Barron DN, West E, Hannan MT. 1994. A time to grow and a time to die: growth and mortality of credit unions in New York City, 1914-1990. American Journal of Sociology 100(2): 381421.

Bernardo AE, Chowdhry B. 2002. Resources, real options, and corporate strategy. Journal of Financial Economics 63(2): 211-234.

Bloch ML. 1949. Apologie pour l'histoire, ou, Métier d'historien. Armand Colin.

Braguinsky S. 2015. Knowledge diffusion and industry growth: the case of Japan's early cotton spinning industry. Industrial and Corporate Change 24(4): 769-790.

Braguinsky S, Hounsell DA. 2015. History and nanoeconomics in strategy and industry evolution research: lessons from the Meiji-Era Japanese cotton spinning industry. Strategic Management Journal 37(1): 45-65.

Braudel F. 1982. Civilization and Capitalism, 15th-18th Century: The Wheels of Commerce. University of California Press: Berkeley, CA. 
Buenstorf G, Klepper S. 2009. Heritage and agglomeration: The Akron tyre cluster revisited. Economic Journal 119(537): 705-733.

Burgelman RA. 1983. A process model of internal corporate venturing in the diversified major firm. Administrative Science Quarterly 1: 223-244.

Carr EH. 1961. What is History? Penguin: London, UK.

Carroll, G. R., Hannan, M. T. 2000. The demography of corporations and industries. Princeton University Press: Princeton, NJ.

Cattani G, Dunbar RL, Shapira Z. 2013. Value creation and knowledge loss: the case of Cremonese stringed instruments. Organization Science 24(3): 813-830.

Chandler AD. 1962. Strategy and Structure: Chapters in the History of the American Industrial Enterprise. MIT Press: Boston.

Chandler AD. 1977. The Visible Hand: The Managerial Revolution in American Business. The Belknap Press of Harvard University Press: Boston.

Chandler AD. 1990. Strategy and Structure: Chapters in the History of the Industrial Enterprise. MIT Press: Cambridge, MA

Chen MJ, Miller D. 2012. Competitive dynamics: Themes, trends, and a prospective research platform. The Academy of Management Annals 6(1): 135-210.

Cipolla CM. 2003. Introduzione Alla Storia Economica. Il Mulino.

Colli A., Fernandez-Perez P. 2020. Historical Methods in Family Business Studies. In De Massis A., Kammerlander N. (eds). 2020. Handbook of Qualitative Research Methods for Family Business. Edward Elgar: Cheltenham Glos, UK.

Collins J, Hall N, Paul LA (eds). 2004. Causation and Counterfactuals. MIT Press: Cambridge, MA.

Colpan A, Hikino T. 2018. Business Groups in the West. Origins, Evolution, and Resilience. Oxford: Oxford University Press.

Cusumano MA, Selby RW. 1995. Microsoft Secrets. First Touchstone: New York.

Cyert RM, March JG. 1963. A Behavioral Theory of the Firm. Englewood Cliffs.

Danneels E. 2011. Trying to become a different type of company: dynamic capability at Smith Corona. Strategic Management Journal 32(1): 1-31.

De Massis A, Frattini F, Kotlar J, Messeni Petruzzelli A, Wright M. 2016. Innovation through tradition: lessons from innovative family businesses and directions for future research. Academy of Management Perspectives 30(1): 93-116.

De Massis A, Kotlar J, Wright M, Kellermanns FW. 2018. Sector-based entrepreneurial capabilities and the promise of sector studies in entrepreneurship. Entrepreneurship Theory and Practice 42(1): 3-23.

De Mey T, Weber E. 2003. Explanation and thought experiments in history. History and Theory 42(1): 28-38.

Dobbin, F., Dowd, T. J. 1997. How policy shapes competition: Early railroad foundings in Massachusetts. Administrative Science Quarterly 42(3), 501-529. 
Durand R. 2003. Predicting a firm's forecasting ability: the roles of organizational illusion of control and organizational attention. Strategic Management Journal 24(9): 821-838.

Durand R, Vaara E. 2009. Causation, counterfactuals, and competitive advantage. Strategic Management Journal 30(12): 1245-1264.

Eisenhardt KM, Martin JA. 2000. Dynamic capabilities: what are they? Strategic Management Journal 21(10-11): 1105-1121.

Eisenhardt KM, Zbaraki MJ. 1992. Strategic decision making. Strategic Management Journal 13(S2): 17-37.

Eliade, M. 1963. Myth and Reality. Trans. Willard R. Trask. Harper \& Row: New York.

Erdogan I, Rondi E, De Massis A. 2019. Managing the tradition and innovation paradox in family firms: A family imprinting perspective. Entrepreneurship Theory \& Practice doi.org/10.1177/1042258719839712.

Ferguson N. 1997. Virtual History: Alternatives and Counterfactuals. Picador: London, UK.

Fischer DH. 1970. Historians' Fallacies: Toward a Logic of Historical Thought. Harper Perennial: New York.

Felin T, Foss NJ, Heimeriks K, Madsen T. 2012. Microfoundations of routines and capabilities: Individuals, processes, and structure. Journal of Management Studies 49(8): 1351-1374.

Felin T, Foss NJ, Ployhart RE. 2015. The microfoundations movement in strategy and organization theory. Academy of Management Annals 9(1): 575-632.

Foss NJ. 2003. Selective intervention and internal hybrids: interpreting and learning from the rise and decline of the Oticon spaghetti organization. Organization Science 14(3): 331-349.

Foss NJ, Lyngsie J, Zahra SA. 2013. The role of external knowledge sources and organizational design in the process of opportunity exploitation. Strategic Management Journal 34(12): $1453-1471$.

Gans, JG, Stern S, Wu J. 2019. Foundations of entrepreneurial strategy. Strategic Management Journal 40(5): 736-756.

Gao C, Zuzul T, Jones G, Khanna T. 2017. Overcoming institutional voids: a reputation-based view of long run survival. Strategic Management Journal 38(11): 2147-2167.

Geroski PA, Mata J, Portugal P. 2010. Founding conditions and the survival of new firms. Strategic Management Journal 31(5): 510-529.

Ghemawat P. 1991. Commitment: The Dynamic of Strategy. The Free Press: New York.

Ghemawat P. 1997. Games Businesses Play: Cases and Models. The MIT Press: Boston.

Godfrey PC, Hassard J, O'Connor ES, Rowlinson M, Ruef M. 2016. What is organizational history? Toward a creative synthesis of history and organization studies. Academy of Management Review 41(4): 590-608.

Granqvist N, Grodal S, Woolley J. 2013. Hedging your bets: explaining executives' market labeling strategies in nanotechnology. Organization Science 24(2): 395-413.

Greve HR, Rao H. 2012. Echoes of the past: Organizational foundings as sources of an institutional legacy of mutualism. American Journal of Sociology 118(3): 635-675. 
Greve HR, Rao H. 2017. Disasters and community resilience: Spanish flu and the formation of retail cooperatives in Norway. Academy of Management Journal 61(1): 5-25.

Greve HR, Seidel M-DL. 2015. The thin red line between success and failure: path dependence in the diffusion of innovative production technologies. Strategic Management Journal 36(4): 475-496.

Greckhamer T, Fumari S, Fiss PC, Aguilera RV. 2018. Studying configurations with qualitative comparative analysis: Best practices in strategy and organization research. Strategic Organization 16(4): 482-495.

Hammond NL, Pearson AW, Holt DT. 2016. The quagmire of legacy in family firms: definition and implications of family and family firm legacy orientations. Entrepreneurship Theory and Practice 40(6): 1209-1231

Hansen ZK, Libecap GD. 2004. Small farms, externalities, and the Dust Bowl of the 1930s. Journal of Political Economy 112(3): 665-694.

Hargadon AB, Douglas Y. 2001. When innovations meet institutions: Edison and the design of the electric light. Administrative Science Quarterly 46(3): 476-501.

Hatch MJ, Schultz M. 2017. Toward a theory of using history authentically: historicizing in the Carlsberg Group. Administrative Science Quarterly 62(4): 657-697.

Hawthorn, G. 1991. Plausible Worlds: Possibility and Understanding in History and the Social Sciences. Cambridge University Press: Cambridge.

Helfat CE, Lieberman MB. 2002. The birth of capabilities: Market entry and the importance of pre-history. Industrial and Corporate Change 11(4): 725-760.

Helfat CE, Petraf MA. 2015. Managerial cognitive capabilities and the microfoundations of dynamic capabilities. Strategic Management Journal 36: 831-850.

Henisz WJ. 2000. The institutional environment for multinational investment. Journal of Law, Economics, \& Organization 16(2): 334-364.

Henisz WJ, Dorobantu S, Nartey LJ. 2014. Spinning gold: The financial returns to stakeholder engagement. Strategic Management Journal 35(12): 1727-1748.

Hennart J, Park Y. 1993. Greenfield vs. acquisition: The strategy of Japanese investors in the United States. Management Science 39(9): 1054-1070.

Holman EA, Silver RC. 1998. Getting 'stuck' in the past: temporal orientation and coping with trauma. Journal of Personality and Social Psychology 74(5): 1146-1163.

Holbrook D., Cohen W.M., Hounshell D.A., Klepper S. 2000. The nature, sources, and consequences of firm differences in the early history of the semiconductor industry. Strategic Management Journal 21(10-11): 1017-1041.

Ingram P, Rao H, Silverman BS. 2012. History in strategy research: what, why and how? In SJ Kahl, BS Silverman, and MA Cusumano (eds). In History and Strategy (pp. 241-273), Emerald Group Publishing Limited.

Jacobides, M.G., Winter, S.G. 2005. The co-evolution of capability and transaction costs: Explaining the institutional structure of production. Strategic Management Journal 26(5): $395-413$. 
Jacobides, M.G., Winter, S.G. 2007. Entrepreneurship and firm boundaries: The theory of a firm. Journal of Management Studies 44(7): 1213-1241.

Jacobides, M.G., Winter, S.G., Kassberger, S.M. 2012. The dynamics of profit, wealth, and competitive advantage. Strategic Management Journal 33(12): 1384-1410.

Jaskiewicz P, Combs JG, Rau SB. 2015. Entrepreneurial legacy: toward a theory of how some family firms nurture transgenerational entrepreneurship. Journal of Business Venturing 30(1): 29-49.

Jones G., Friedman W. 2017. Debating methodology in business history. The Business History Review 91(Autumn): 443-455.

Kahl SJ, Silverman BS, Cusumano MA. 2012. The integration of history and strategy research. In SJ Kahl, BS Silverman, and MA Cusumano (eds). In History and Strategy (pp. ix-xxi), Emerald Group Publishing Limited.

Kaplan S, Orlikowski WJ. 2013. Temporal work in strategy making. Organization Science 24(4): 965-995.

Katila R. 2002. New product search over time, past ideas in their prime? Academy of Management JournaL 45(5): 995-1010.

Keats-Rohan KS. 2007. Prosopography Approaches and Applications: A Handbook. Occasional Publications UPR: Oxford.

Kieser A. 1994. Why organization theory needs historical analyses - and how this should be performed. Organization Science 5(4): 608-620.

Kipping M, Üsdiken B. 2014. History in organization and management theory: more than meets the eye. The Academy of Management Annals 8(1): 535-588.

Kirsch DA. 2000. The Electric Vehicle and the Burden of History (New Brunswick, NJ: Rutgers University Press).

Kirsch DA, Mom G. 2002. Visions of transportation: the EVC and the transition from service-toproduct-based mobility. Business History Review 76(1): 75-110.

Klepper, S. 2002. Firm survival and the evolution of oligopoly. RAND Journal of Economics 33(1): 37-61.

Klepper S. 2007. Disagreements, spinoffs, and the evolution of Detroit as the capital of the U.S. automobile industry. Management Science 53(4): 616-631.

Klepper S. 2011. Nano-economics, spinoffs, and the wealth of regions. Small Business Economics 37(2): 141-154.

Klepper S. 2016. Experimental Capitalism: The Nanoeconomics of American High-Tech Industries. Princeton University Press: Princeton.

Klepper S, Simons K.L. 2000. Dominance by birthright: Entry of prior radio producers and competitive ramifications in the U.S. television receiver industry. Strategic Management Journal 21(10-11): 997-1016.

Klepper S, Simons K. 2002. The making of an oligopoly: firm survival and technological change in the evolution of the tire industry. Journal of Political Economy 108(4): 728-760. 
Kline, P., Petkova N, Williams H, Zidar O 2019. Who Profits from Patents? Rent-sharing at Innovative Firms. The Quarterly Journal of Economics. Forthcoming.

Kluppel L, Pierce L, Snyder J. 2018. The deep historical roots of organization and strategy: traumatic shocks, culture and institutions. Organization Science 29(4): 702-721.

Kor YY, Mahoney JT. 2004. Edith Penrose's (1959) contributions to the resource-based view of strategic management. Journal of Management Studies 41(1): 183-191.

Koselleck R. 2004. Futures Past: on the Semantics of Historical Time. Columbia University Press: New York.

Kotlar J, De Massis A. 2013. Goal setting in family firms: goal diversity, social interactions, and collective commitment to family-centered goals. Entrepreneurship Theory \& Practice 37(6): $1263-1288$.

Leblebici H. 2012. The evolution of alternative business models and the legitimization of universal credit card industry: exploring the contested terrain where history and strategy meet. In Kahl SJ, Silverman BS, Cusumano MA. (eds). Advances in Strategic Management (pp. 89-115), Emerald Group: Bingey, UK.

Leonard-Barton D. 1992. Core capabilities and core rigidities: a paradox in managing new product development. Strategic Management Journal 31(S1): 111-125.

Lewis D. 1973. Counterfactuals. Harvard University Press: Cambridge, MA.

Lewis D. 1986. Philosophical Papers: Volume II. Oxford University Press: Oxford, UK.

Lieberman M, Montgomery D. 1988. First mover (dis)advantages: retrospective and link with the resource-based view. Strategic Management Journal 29(12): 1111-1126.

Lippmann S, Aldrich, HE. Forthcoming. The temporal dimension of context. In Gartner WB, Welter F. (eds). A Research Agenda for Entrepreneurship and Context. Edward Elgar: New York.

Lippman SA, Rumelt RP. 1982. Uncertain imitability: an analysis of interfirm differences in efficiency under competition. The Bell Journal of Economics 13(2): 418-438.

Lord RG, Dinh JE, Hoffman EL. 2015. A quantum approach to time and organizational change. Academy of Management Review 40(2): 263-290.

Malerba F, Nelson R, Orsenigo L, Winter S. 1999. 'History-friendly' models of industry evolution: the computer industry. Industrial and Corporate Change 8(1): 3-40.

Malerba F, Nelson R, Orsenigo L, Winter S. 2001. Competition and industrial policies in a 'history friendly' model of the evolution of the computer industry. International Journal of Industrial Organization 19(5): 635-664.

Malerba F, Nelson R, Orsenigo L, Winter S. 2008. Vertical integration and disintegration of computer firms: a history-friendly model of the coevolution of the computer and semiconductor industries. Industrial and Corporate Change 17(2): 197-231.

Malerba F, Orsenigo L. 2002. Innovation and market structure in the dynamics of the pharmaceutical industry and biotechnology: towards a history-friendly model. Industrial and Corporate Change 11(4): 667-703.

Marquis C, Tilcsik A. (2013). Imprinting: toward a multilevel theory. Academy of Management Annals 7(1): 195-245 
McKendrick DG, Carroll GR. 2001. On the genesis of organizational forms: evidence from the market for disk arrays. Organization Science 12(6):661-682.

McKenna CD. 2006. The World's Newest Profession: Management Consulting in the Twentieth Century. Cambridge University Press: Cambridge, MA.

Menon, A, Yao, D. 2017. Elevating repositioning costs: Strategy dynamics and competitive interactions. Strategic Management Journal, 38(10): 1953-1963.

Miller KD, Gomes E, Lehman DW. 2018. Strategy restoration. Long Range Planning doi.org/10.1016/j.lrp.2018.10.005.

Moeen M. 2017. Entry into nascent industries: Disentangling a firm's capability portfolio at the time of investment versus market entry. Strategic Management Journal 38(10): 1986-2004.

Montgomery DB, Lieberman ML. 1988. First mover advantages. Strategic Management Journal 9(1): 41-58.

Morgan SL, Winship C. 2007. Counterfactuals and Causal inference: Methods and Principles for Social Research. Cambridge University Press: Cambridge, UK.

Murmann JP. 2012. Marrying history and social science in strategy research. In Kahl SJ, Silverman BS, Cusumano MA. (eds). Advances in Strategic Management (pp. 89-115), Emerald Group: Bingey, UK.

Nelson RR, Winter SG. 1982. An Evolutionary Theory of Economic Change. Harvard University Press: Cambridge, Mass.

Oliver C. 1997. Sustainable competitive advantage: combining institutional and resource-based views. Strategic Management Journal 18(9): 697-713.

Oxley JE, Rivkin JW, Ryall MD. 2010. The strategy research initiative: recognizing and encouraging high-quality research in strategy. Strategic Organization 8(4): 377-386.

Pearl J. 2000. Causality: Models, Reasoning, and Inference. Cambridge University Press: Cambridge, UK.

Penrose ET. 1959. The Theory of the Growth of the Firm. Oxford University Press: Oxford.

Penrose ET. 1960. The growth of the firm - a case study: the Hercules Powder company. Business History Review 34(1): 1-23.

Peteraf MA. 1993. The cornerstones of competitive advantage: a resource-based view. Strategic Management Journal 14(3): 179-191.

Pettigrew AM. 1985. The Awakening Giant: Continuity and Change in ICI. Blackwell: Oxford.

Ragin C. 2014. The Comparative Method: Moving beyond Qualitative and Quantitative Strategies (Berkeley: University of California Press)

Ramos-Rodriquez A-R, Ruiz-Navarro J. 2004. Changes in the intellectual structure of strategic management research: a bibliometric study of the Strategic Management Journal. Strategic Management Journal 25(10): 981-1004.

Ranke L. 1824. Zur Kritik neuerer Geschichtshriber. Leipzig.

Rao H, Dutta S. 2012.Free spaces as organizational weapons of the weak: Religious festivals and regimental mutinies in the 1857 Bengal Native Army. Administrative Science Quarterly 57(4): 625-668.

Ries E. 2017. The Startup Way: How Modern Companies Use Entrepreneurial Management to Transform Culture and Drive Long-Term Growth (New York: Currency). 
Rowlinson, M., Hassard, J. 1993. The invention of corporate culture: A history of the histories of Cadbury. Human Relations, 46: 299-326.

Rumelt RP, Schendel D, Teece DJ. 1991. Strategic management and economics. Strategic Management Journal 12(S2): 5-29.

Schultz M, Hernes T. 2013. A temporal perspective on organizational identity. Organization Science 24(1): 1-21.

Selznick P. 1957. Leadership in Administration. Harper \& Row: New York.

Shipp AJ, Edwards JR, Lambert LS. 2009. Conceptualization and measurement of temporal focus: the subjective experience of the past, present and future. Organizational Behavior and Human Decision Processes 110(1): 1-22.

Silverman BS, Ingram P. 2017. Asset ownership and incentives in early shareholder capitalism: Liverpool shipping in the eighteenth century. Strategic Management Journal 38(4): 854-875.

Simsek Z, Fox BC, Heavey C. 2015. What's past is prologue. A framework, review, and future directions for organizational research on imprinting. Journal of Management 41(1): 288-317.

Stinchcombe AL. 1965. Organizations and social structure. Handbook of Organizations 44(2): $142-193$.

Stone L. 1971. Prosopography. Daedalus 100: 46-79.

Suddaby R, Foster WM. 2017. History and organizational change. Journal of Management 43(1): 19-38.

Suddaby R, Foster WM, Trank C. 2010. Rhetorical history as a source of competitive advantage. Advances in Strategic Management 27: 147-173.

Teece DJ. 2007. Explicating dynamic capabilities: The nature and microfoundations of (sustainable) enterprise performance. Strategic Management Journal 28(13): 1319-1350.

Teece DJ. 2012. Alfred Chandler and "capabilities" theories of strategy and management. In W. Lazonick and D.J. Teece (eds.) Management Innovation. Essays in the Spirit of Alfred D. Chandler (pp. 68-88), Oxford University Press: Oxford.

Teece DJ, Pisano G, Shuen A. 1997. Dynamic capabilities and strategic management. Strategic Management Journal, 18(7): 509-533.

Tetlock PE, Belkin A (eds). 1996. Counterfactual Thought Experiments in World Politics. Princeton University Press: Princeton, NJ.

Tetlock PE, Lebow RN, Parker NG (eds). 2006. Unmaking the West: What-if Scenarios that Rewrite World History. Cambridge University Press: New York.

Tilcsik, A. 2012. Remembrance of Things Past: Individual Imprinting in Organizations. Harvard University: Cambridge, MA.

Tosh J. 2010. The Pursuit of History. Routledge.

Tripsas, M., Gavetti, G. 2000. Capabilities, cognition, and inertia: Evidence from digital imaging. Strategic Management Journal 21(10-11), 1147-1161.

Vaara E, Lamberg J-A. 2016. Taking historical embeddedness seriously: three historical approaches to advance strategy process and practice research. Academy of Management Review 41(4): 633-657.

Van de Ven AH, Huber GP. 1990. Longitudinal field research methods for studying processes of organizational change. Organization Science 1(3): 213-219. 
Weber K, Dacin MT. 2011. The cultural construction of organizational life: introduction to the special issue. Organization Science 22(2): 287-298.

Weindruch B. 2016. Start with the Future and Work back: A Heritage Management Manifesto. Hamilton: London, UK.

Wernerfelt B. 1984. A resource-based view of the firm. Strategic Management Journal 5(2): 171-180.

White H. 1987. The Content of the Form: Narrative Discourse and Historical Representation. John Hopkins University Press: Baltimore, MD.

Whittington R, Mayer M. 2000. The European Corporation: Strategy, Structure and Social Science. Oxford University Press: Oxford.

Whittington R. 2008. Alfred Chandler, founder of strategy: lost tradition and renewed inspiration. Business History Review 82(2): 267-277.

Wiggins RR, Ruefli TW. 2002. Sustained competitive advantage: temporal dynamics and the incidence and persistence of superior economic performance. Organization Science 13(1): 81-105.

Winter, S. G. 2003. Understanding dynamic capabilities. Strategic Management Journal 24(10): 991-995.

Woodward J. 2003. Making Things Happen: A Theory of Causal Explanation. Oxford University Press: Oxford, UK.

Ybema S. 2014. The invention of transitions: History as a symbolic site for discursive struggles over organizational change. Organization 21(4): 495-513.

Zhao M. 2006. Conducting R\&D in countries with weak intellectual property rights protection. Management Science 52(8): 1185-1199.

Table 1. Contemporary examples of history-informed strategy research

\begin{tabular}{|c|c|c|c|c|}
\hline Title & Authors & Topic & Empirical setting & History-informed strategy dimension \\
\hline $\begin{array}{l}\text { Centers of Gravity: } \\
\text { The Effect of Shared } \\
\text { Leadership and } \\
\text { Stability in Top } \\
\text { Management Teams on } \\
\text { Firm Growth and } \\
\text { Industry Evolution }\end{array}$ & $\begin{array}{l}\text { Agarwal, } \\
\text { Braguinsky } \\
\text { \& Ohyama } \\
\text { (this issue) }\end{array}$ & $\begin{array}{l}\text { The effect of Top } \\
\text { Management Team (TMT) } \\
\text { shared and stable leadership } \\
\text { on industry evolution }\end{array}$ & $\begin{array}{l}25 \text { Japanese cotton } \\
\text { spinning Industry }\end{array}$ & History to Theory \\
\hline $\begin{array}{l}\text { The nano-economics of } \\
\text { firm-level decision- } \\
\text { making and industry } \\
\text { evolution: evidence } \\
\text { from } 200 \text { years of } \\
\text { paper and pulp making }\end{array}$ & $\begin{array}{l}\text { Lambert \& } \\
\text { Peltoniemi } \\
\text { (this issue) }\end{array}$ & $\begin{array}{l}\text { How entrepreneurs and } \\
\text { managers take decisions } \\
\text { under pressures caused by } \\
\text { institutional and historical } \\
\text { dynamics }\end{array}$ & $\begin{array}{l}\text { Finnish paper and } \\
\text { pulp industry }\end{array}$ & History to Theory and History in Theory \\
\hline
\end{tabular}




\begin{tabular}{|c|c|c|c|c|}
\hline $\begin{array}{l}\text { The origins of firm } \\
\text { strategy: leaning by } \\
\text { economic } \\
\text { experimentation and } \\
\text { strategic pivots in the } \\
\text { early automotive } \\
\text { industry }\end{array}$ & $\begin{array}{l}\text { Pillai, } \\
\text { Goldfarb } \\
\text { \& Kirsch } \\
\text { (this issue) }\end{array}$ & $\begin{array}{l}\text { The effectiveness of } \\
\text { economic experimentation } \\
\text { as a learning mechanism }\end{array}$ & $\begin{array}{l}\text { Sample of all auto } \\
\text { manufacturers who } \\
\text { produced } \\
\text { automobiles and } \\
\text { displayed them in } \\
\text { the New York Auto } \\
\text { Show between } \\
1901 \text { and } 1918\end{array}$ & History to Theory and History in Theory \\
\hline $\begin{array}{l}\text { The evolution of } \\
\text { strategic guideposts at } \\
\text { the Gallagher Group: } \\
\text { linking history to } \\
\text { strategic decision- } \\
\text { making }\end{array}$ & $\begin{array}{l}\text { Sinha, } \\
\text { Jaskiewicz, } \\
\text { Gibb \& } \\
\text { Combs } \\
\text { (this issue) }\end{array}$ & $\begin{array}{l}\text { How historical narratives } \\
\text { and strategic decision- } \\
\text { making are connected } \\
\text { through "strategic } \\
\text { guideposts", i.e. historically } \\
\text { grounded rules that are } \\
\text { imprinted in decision- } \\
\text { makers and that direct } \\
\text { organizations' decisions and } \\
\text { actions }\end{array}$ & $\begin{array}{l}\text { In-depth historical } \\
\text { case study of the } \\
\text { Gallagher Group }\end{array}$ & History in Theory \\
\hline $\begin{array}{l}\text { History and the micro- } \\
\text { foundations of } \\
\text { dynamic capabilities }\end{array}$ & $\begin{array}{l}\text { Suddaby, } \\
\text { Coraiola, } \\
\text { Harvey \& } \\
\text { Foster (this } \\
\text { issue) }\end{array}$ & $\begin{array}{l}\text { How different cognitive } \\
\text { interpretations of history } \\
\text { can be mobilized by } \\
\text { managers to sense, seize and } \\
\text { reconfigure around } \\
\text { opportunities made } \\
\text { available by understanding } \\
\text { the invisible thread of } \\
\text { technology }\end{array}$ & Conceptual paper & History in Theory \\
\hline
\end{tabular}

\section{Table 2. Examples of opportunities to apply historical research methods in history-informed strategy research ("history to theory" research directions)}

\begin{tabular}{|c|c|}
\hline Direction of research & Examples of research questions \\
\hline $\begin{array}{l}\text { Building new datasets } \\
\text { and addressing } \\
\text { methodological } \\
\text { challenges }\end{array}$ & $\begin{array}{l}\text { Q1: How can historical research methods (and historiographical approaches) be } \\
\text { employed by strategy scholars to develop more comprehensive strategy theories and/or } \\
\text { extend and/or enrich current theories of strategic behavior? } \\
\text { Q2: What is the potential of historical research methods in enabling the examination of } \\
\text { strategy phenomena at multiple levels of analysis? } \\
\text { Q3: How can strategy scholars effectively develop novel quantitative and qualitative } \\
\text { datasets tracing over time how organizations, groups and individuals - by taking } \\
\text { decisions, acting in a particular historically embedded context, and mutually } \\
\text { interacting - have performed, including building sustainable competitive advantages? } \\
\text { Are there available datasets used by historians that could be used by strategy scholars? } \\
\text { What kind of partnerships are required with historians? }\end{array}$ \\
\hline
\end{tabular}




\begin{tabular}{|l|l|}
\hline & $\begin{array}{l}\text { Q4: How can strategy scholars leverage the comprehensiveness that historical research } \\
\text { methods provide, going beyond the qualitative and quantitative methods that are typical } \\
\text { of management scholars? }\end{array}$ \\
\hline $\begin{array}{l}\text { Applying history- } \\
\text { informed approaches } \\
\text { and modeling }\end{array}$ & $\begin{array}{l}\text { Q5: How can approaches commonly used in historical analysis (e.g., counterfactual } \\
\text { history approaches and related history techniques, causal modeling) be applied by } \\
\text { strategy scholars to understand the role of history and the past in strategy processes? } \\
\text { Q6: What are the approaches that strategy scholars can employ to successfully use } \\
\text { historical research methods to build and test theoretical interpretations of strategy } \\
\text { processes and outcomes? } \\
\text { Q7: How has an outlier firm been particularly (un)successful in developing a sustainable } \\
\text { competitive advantage over a long time? }\end{array}$ \\
\hline $\begin{array}{l}\text { Thought experiments } \\
\text { and fiction approaches }\end{array}$ & $\begin{array}{l}\text { Q8: How can strategy scholars build theory about strategic phenomena under rare } \\
\text { conditions by applying "what-if" reasoning, and contrasting conceptual development } \\
\text { with well-established historical events? } \\
\text { Q9: What are the rules that academic historians follow when addressing these what-if } \\
\text { questions through thought experiments, and how can such rules be applied to understand } \\
\text { the mechanisms regulating strategy phenomena? } \\
\text { Q10: How does a firm's strategic behavior, or the sources of its competitive advantage } \\
\text { or of other performance outcomes such as growth and survival, change under the effect } \\
\text { of historical events such as a natural disaster, a political upheaval or terrorist attack? }\end{array}$ \\
\hline
\end{tabular}




\section{Table 3. Examples of opportunities to incorporate history and the past in strategy theories ("history in theory" research directions)}

\begin{tabular}{|c|c|}
\hline Direction of research & Examples of research questions \\
\hline $\begin{array}{l}\text { Realizing a contextualist } \\
\text { approach in strategy } \\
\text { studies }\end{array}$ & $\begin{array}{l}\text { Q1: How can strategy phenomena be better theorized when the historical context where } \\
\text { they take place, and the complex temporal dimensions through which they occur, are } \\
\text { explicitly taken into account? } \\
\text { Q2: How can historical research methods and historical data be useful to strategy } \\
\text { research for understanding the context of contemporary phenomena, identifying } \\
\text { sources of exogenous variations, developing and testing informed causal inferences } \\
\text { and theories, and supporting analyses of path dependence? } \\
\text { Q3: Historians' traditional praxis includes classifying the sources of information } \\
\text { according to chronology and space, and contextualizing them to assess their reliability, } \\
\text { and to understand the reasons for their contents. How can this praxis help strategy } \\
\text { scholars to apply a more contextualist approach in their studies? } \\
\text { Q4: Can historical contextualization of the current moment in strategy thinking and } \\
\text { practice help shed light on how strategy in the present is similar or different from the } \\
\text { past? } \\
\text { Q5: How do organizations, groups and individuals use the past to give meaning to the } \\
\text { present, inform their expectations about the future, and take strategic decisions? } \\
\text { Q6: How do the past and the historical context inform how organizational goals are } \\
\text { set? } \\
\text { Q7: How do the past and the historical context inform how future technology and } \\
\text { market trends are forecast? } \\
\text { Q8: How do the past and the historical context inform how new business opportunities } \\
\text { are identified, evaluated and exploited? } \\
\text { Q9: How can the assumptions behind path dependence-based predictions be } \\
\text { understood when the historical context is better taken into account? } \\
\text { Q10: How did specific and non-recurrent events or actions in the past lead to particular } \\
\text { strategic behaviors, and to the development of organizational capabilities (or lack } \\
\text { thereof)? } \\
\text { Q11: What are the advantages of employing a historically-embedded approach to } \\
\text { improve current understanding of how organizations learn, innovate and take strategic } \\
\text { decisions over time? How can such approaches be adopted by strategy scholars? } \\
\text { Q12: How is history used by strategists and in the strategy process? What is the } \\
\text { relationship between narrative, story-telling and history in the strategy process? }\end{array}$ \\
\hline $\begin{array}{l}\text { Leveraging knowledge } \\
\text { and resources pertaining } \\
\text { to the past to achieve and } \\
\text { maintain a competitive } \\
\text { advantage and/or other } \\
\text { performance outcomes }\end{array}$ & $\begin{array}{l}\text { Q13: How do organizations search for, access and use knowledge and resources } \\
\text { pertaining to different points in the past through acts directed toward innovation, } \\
\text { entrepreneurship or organizational renewal? } \\
\text { Q14: What are the firm-, individual- and group-level capabilities required to } \\
\text { successfully search, identify and recombine knowledge resources coming from the } \\
\text { past? } \\
\text { Q15: How do firms learn to innovate their products, services, business models, } \\
\text { procedures and strategies from the past? } \\
\text { Q16: How do innovation processes and practices evolve over time, and how are they } \\
\text { shaped by the interactions between firms and the past? } \\
\text { Q17: How do temporal search processes unfold over time and what are the antecedents } \\
\text { and consequences on resource-based competitive advantage and firm performance } \\
\text { (e.g., growth, survival)? How should such processes, sources and consequences be } \\
\text { placed in the historical context in which knowledge is generated, searched, retrieved } \\
\text { and used for innovation and change purposes? } \\
\text { Q18: How can a better appreciation of an organization's historical and past resources } \\
\text { help overcome "recency bias" and incorporate concepts emphasizing the dark side of } \\
\text { past resources (e.g., path dependency, liability of senescence, core rigidity) }\end{array}$ \\
\hline
\end{tabular}




\begin{tabular}{|l|l|}
\hline $\begin{array}{l}\text { Challenging the linear } \\
\text { conceptualization of time } \\
\text { in strategy studies }\end{array}$ & Q19: What were the unpredictable, non-recurrent events that changed the course of \\
history and the evolution of organizations? \\
Q20: How do different individuals, groups and firms perceive time differently when it \\
is conceived as a complex, socially constructed concept? \\
Q21: How do individuals, groups and firms conceive of time in practice, and allocate \\
their attention differently to the past, present and future? \\
Q22: Do organizational decision makers vary in their temporal foci/orientation and \\
shift their attention differently to various points in time? If yes, how and under what \\
circumstances? \\
Q23: How does decision makers' temporal focus/orientation change under the \\
influence of different individual-, firm-, or country-level variables? \\
Q24: Do the organizational decision makers' perceptions of the future affect strategy \\
making processes as compared to their perceptions of the past? \\
Q25: How do different temporal foci and/or orientations influence the performances of \\
teams and organizations?
\end{tabular}

